\title{
Needs Assessment of Information and Communication Technology Literacy (ICT Literacy) of Students in Secondary Educational Service Area
}

\author{
https://doi.org/10.3991/ijet.v11i12.5798 \\ Patcharapon Thammasaeng ${ }^{1}$, Phadungchai Pupat ${ }^{1}$ and Sawas Petchaboon ${ }^{2}$ \\ ${ }^{1}$ King Mongkut's Institute of Technology Ladkrabang, Bangkok, Thailand \\ ${ }^{2}$ Horwang Secondary School, Bangkok, Thailand
}

\begin{abstract}
The objectives of this research were (1) to study authentic situations of Information Communication Technology literacy of students in secondary educational service area (2) to compare situations of ICT literacy of students in secondary educational service area, divided in each levels (3) to examine need assessment of ICT literacy of students in secondary educational service area (4) to prioritise needs assessment of ICT literacy of students in secondary educational service area. The sample consisted of 340 ICT teachers, teaching in Grade 7 to 9 from schools in secondary educational service area in 2015 . The sampling group was drawn from 2,343 ICT teachers by using multi-stage sampling technique. Data were collected by using questionnaire, in order to collect data of expected and authentic situations of students understanding about ICT. The questionnaires include 76 questions from 7 components in which the questionnaires were approved content validity from experts at level of 0.98 and 0.99 , respectively. The statistics were used to analyse the data as follows: mean (M), standard deviation (SD), one-way ANOVA, Matrix analysis, priority needs index modified (PNI modified). The study revealed that (1) authentic situation of ICT literacy of students in secondary educational service area was found at "Moderate" level (2) authentic situation of ICT literacy of students in secondary educational service area, divided in levels was found "No different" (3) authentic situation of need assessment in 7 aspects (Define, Access, Manage, Evaluate, Integrate, Create and Communicate) fell in the third quadrant, in which means "Need to be improved" (4) prioritise need assessment from the most necessary to the least was found as follows: Manage, Evaluate, Create, Define, Access, Integrate and Communicate, respectively.
\end{abstract}

Index Terms-ICT Literacy, Need Assessment, ICT

\section{INTRODUCTION}

Nowadays, Information and Communication Technology (ICT) influences on human in many ways. The ICT plays an important role to improve human's quality of life. To improve human capacity, it is needed to help them to be well-rounded; having some important skills in order to work and live effectively. The significant skills for the 21 st century are such as learning and innovation skills, information, media and technology skills, life and career skills. Such skills help promote life-long learning in human [1]. In particular, ICT literacy skill is important for human everyday life. The ICT literacy means a person having the ability to use computer, communication tools and social network appropriately; can define, access, manage, evaluate, integrate, create and communicate with consciousness and responsibility. Achieving ICT literacy skill is useful in researching, setting up system and evaluating information in which can promote effective learning and working.

Information has increased because of the development of ICT. Such development has impacts in numerous ways, especially an individual potential to achieve in the $21 \mathrm{st}$ century [2]. In many countries, they set up what level of ICT literacy population should have. For example, In Malaysia, it is indicated that an individual should have the capacity to search, gather and share information to help solve problems and make decision ethically and responsibly. The expected level of an individual achieving ICT literacy is that the individuals can increase their learning and using ICT to think creatively and generate innovation [3]. Moreover, the Australian of Office of Education has identified about common framework of ICT literacy: create and share information and use ICT with responsibility [4].

In addition, apart from the change of individuals, the ICT is a significant force of changes of organisational culture. Also, the ICT is an important indicator to inform characteristics, skills and abilities of employees. The ICT can enhance individuals' characteristics and impact on their beliefs in various ways [5]. Seeing from such major impacts, the Educational Testing Service (ETS) points out the important of ICT literacy and indicates the standards which includes 7 components such as define requirements, access, manage, evaluate, integrate, create and communicate [6]. The standards are widely used to measure individuals' ability to analyse and solve problem of using ICT in digital environment and to be a framework and guidelines to enhance people ICT literacy.

In Thailand, the Basic Education Core Curriculum indicates standards and indicators of ICT literacy in Career and Technology department that students should be achieved ICT literacy according to the core curriculum. The curriculum indicates that students should achieve the following (1) ICT literacy; be well-rounded, can access and develop (2) use ICT appropriately and (3) media literacy [7]. However, the International Computer and Infor- 
mation Literacy Study (ICILS 2013) reveals that students capacity of ICT and media literacy have not reach the core curriculum standards. Thailand ranks at 17 th from 18 country participants [8]. The finding indicates that ICT education in Thailand have not achieved the goals and it needs to be developed. Therefore, the researcher is interested to do this needs assessment and use as a tool to indicate the problem. This study intends to find data of what situation should be and what authentic situation is. Then bring it to analyse in order to know what the problems are. This can help solve problem of ICT literacy of students effectively.

\section{OBJECTIVE}

1. To study authentic situations of Information Communication Technology literacy of students in secondary educational service area.

2. To compare situations of ICT literacy of students in secondary educational service area, divided in each levels.

3. To examine need assessment of ICT literacy of students in secondary educational service area.

4. To prioritise needs assessment of ICT literacy of students in secondary educational service area.

\section{CONCEPTUAL FRAMEWORK}

In this study, the research follows the standards of ICT literacy of the Educational Testing Service (ETS) [6] as research framework which includes 7 components as follows:

1. Define means ability to find required information, to find reliable information and to consider benefits and initial values.

2. Access means ability to know how to search information, to set strategies to search and to collect information

3. Manage means ability to organise information with basic system, to classify and to retain information further use.

4. Evaluate means ability to make judgements about quality, relevance, usefulness and efficiency of information.

5. Integrate means ability to interpret and represent information including summarising, comparing and contrasting.

6. Create means ability to generate information such as adapting, applying. designing or inventing and to use information to communicate with others.

7. Communicate means ability to use technology tools to present, communicate and receive information.

\section{Methodology}

\section{A. Population and Samples}

Population: 2,343 ICT teachers teaching Grade 7 to 9 from schools in secondary educational service area, under the Office of Basic Educational Commission (OBEC) in 2015.

Samples: 340 ICT teachers teaching Grade 7 to 9 from schools in secondary educational service area, under the Office of Basic Educational Commission (OBEC) in 2015 calculated from Taro Yamane formula at error 0.5 [9] and used multi-stage random sampling.

\section{B. Variables}

1. Independent Variable: Levels of students divided in 3 levels; Grade 7, 8 and 9.

2. Dependent Variable: (1) Authentic situation of ICT literacy of students in secondary educational service area according to perception of teachers (2) Need assessment of ICT literacy of students in secondary educational service area according to perception of teachers.

\section{Research Tools}

The questionnaire scale level 5 contains 76 questions from 7 components to explore expected and authentic situations of ICT literacy of students. The questionnaires were approved content validity from experts and had the following results: (1) the questionnaires to explore expected situation have reliability at 0.98 and (2) the questionnaires to explore authentic situation have reliability at 0.99 .

\section{Data Collection}

The data were collected in 2015 by sending online questionnaires out to participants. The participants evaluate expected and authentic situations of students' ICT literacy. The scales are as follows: $1=$ very poor, $2=$ poor, 3 = fair, $4=$ good, $5=$ excellent

\section{E. Data Analysis}

1. The data of level of students' ICT literacy were analysed with basic statistics; Mean (M) and Standard Deviation (SD).

2. The data of comparison of authentic situation were analysed with one-way ANOVA.

3. The data of need assessment situation were analysed with Matrix analysis [10] as follows:

Quadrant 1 is better than set criteria

Quadrant 2 is good according to set criteria

Quadrant 3 is poor; need to be improved

Quadrant 4 is not reach to set criteria

4. The data of priority of need assessment were analysed with Priority Needs Index Modified (PNI modified)

$$
\mathrm{PNI}_{\text {modified }}=\frac{\mathrm{I}-\mathrm{D}}{\mathrm{D}}
$$

$\mathrm{I}=$ Mean of expected situation

$\mathrm{D}=$ Mean of authentic situation

\section{RESUlTS}

\section{A. General information of participants}

From Table 1, the questionnaires were answered by 340 participants from 3 levels: 111 from Grade 7 teachers $=32.65 \%, 114$ from Grade 8 teachers $=33.53 \%$ and 115 from Grade 9 teachers $=33.82 \%$

\section{B. Authentic situation of ICT literacy of students in secondary educational service area}

Table II shows authentic situation of students' ICT literacy according to perceptions of teachers. The results shows all components are at "Fair" or "Moderate" level ( $\bar{X}=2.88$, S.D. $=0.69)$. The highest average is Grade $9(\bar{X}$ $=2.95$, S.D. $=0.55)$, then Grade $7(\bar{X}=2.86$, S.D. $=0.75)$ and 
PAPER

NEEDS ASSESSMENT OF INFORMATION AND COMMUNICATION TECHNOLOGY LiTERACY (ICT LiTERACY) OF STUDENTS...

Grade $8(\overline{\mathrm{X}}=2.82$, S.D. $=0.74)$. When considering each components, it shows that Define, Access, Manage Integrate and Create of Grade 9 have the highest average, Grade 7 and 8, respectively. For Evaluate component, Grade 7 is the highest, Grade 8 and the least Grade 9, respectively.

\section{Comparison of authentic situation of ICT literacy of students in secondary educational service area divided by levels}

The Table III shows authentic situation of students' ICT literacy divided by level of study. The results reveal that student's ICT literacy has "No different" as shown in Table III that average mean of all components is "No different" at significant 0.5 .

\section{The results of need assessment of ICT literacy of students in secondary educational service area.}

From Figure 1, the Matrix analysis shows that need assessment of students' ICT literacy falls in Quadrant 3. The need assessment of 7 components (Define, Access, Man- age, Evaluate, Integrate, Create and Communicate) shows the students' ICT literacy levels need to be improved.

\section{E. Results of priority of need assessment of students' ICT literacy}

The Table IV shows $\mathrm{PNI}_{\text {modified }}$ between 0.60-0.74 ranking from the most needs to the least one. The components that needs to be improved is Manage $\left(\mathrm{PNI}_{\text {modified }}=\right.$ $0.74)$, Evaluate $\left(\mathrm{PNI}_{\text {modified }}=0.70\right)$, Create $\left(\mathrm{PNI}_{\text {modified }}=\right.$ $0.68)$, Define $\left(\mathrm{PNI}_{\text {modified }}=0.67\right)$, Access $\left(\mathrm{PNI}_{\text {modified }}=\right.$ $0.66)$, Integrate $\left(\mathrm{PNI}_{\text {modified }}=0.65\right)$ and Communicate $\left(\mathrm{PNI}_{\text {modified }}=0.60\right)$, respectively.

TABLE I.

FREQUENCY AND AVERAGE PERCENTAGE OF PARTICIPANTS DIVIDED IN 3 LEVELS

\begin{tabular}{|c|c|c|}
\hline Level & Number & Percentage (\%) \\
\hline Grade 7 & 111 & 32.65 \\
\hline Grade 8 & 114 & 33.53 \\
\hline Grade 9 & 115 & 33.82 \\
\hline Total & 340 & 100.00 \\
\hline
\end{tabular}

TABLE II.

MEAN (M) AND STANDARD DEVIATION (S.D.) OF AUTHENTIC SITUATION OF STUDENTS' ICT LITERACY (N=340)

\begin{tabular}{|c|c|c|c|c|}
\hline Components & Level of Study & $\bar{X}$ & S.D. & Level \\
\hline \multirow{4}{*}{ Define } & Grade 7 & 2.84 & 0.70 & Fair \\
\hline & Grade 8 & 2.83 & 0.74 & Fair \\
\hline & Grade 9 & 2.86 & 0.64 & Fair \\
\hline & Total & 2.84 & 0.69 & Fair \\
\hline \multirow{4}{*}{ Access } & Grade 7 & 2.90 & 0.82 & Fair \\
\hline & Grade 8 & 2.84 & 0.85 & Fair \\
\hline & Grade 9 & 2.91 & 0.67 & Fair \\
\hline & Total & 2.88 & 0.78 & Fair \\
\hline \multirow{4}{*}{ Manage } & Grade 7 & 2.77 & 0.92 & Fair \\
\hline & Grade 8 & 2.68 & 0.90 & Fair \\
\hline & Grade 9 & 2.91 & 0.68 & Fair \\
\hline & Total & 2.79 & 0.84 & Fair \\
\hline \multirow{4}{*}{ Evaluate } & Grade 7 & 2.89 & 0.74 & Fair \\
\hline & Grade 8 & 2.80 & 0.73 & Fair \\
\hline & Grade 9 & 2.85 & 0.55 & Fair \\
\hline & Total & 2.85 & 0.68 & Fair \\
\hline \multirow{4}{*}{ Integrate } & Grade 7 & 2.85 & 0.75 & Fair \\
\hline & Grade 8 & 2.81 & 0.71 & Fair \\
\hline & Grade 9 & 2.95 & 0.56 & Fair \\
\hline & Total & 2.87 & 0.68 & Fair \\
\hline \multirow{4}{*}{ Create } & Grade 7 & 2.82 & 0.85 & Fair \\
\hline & Grade 8 & 2.82 & 0.84 & Fair \\
\hline & Grade 9 & 3.02 & 0.65 & Fair \\
\hline & Total & 2.89 & 0.79 & Fair \\
\hline \multirow{4}{*}{ Communicate } & Grade 7 & 2.91 & 0.79 & Fair \\
\hline & Grade 8 & 2.95 & 0.82 & Fair \\
\hline & Grade 9 & 3.13 & 0.63 & Fair \\
\hline & Total & 3.00 & 0.76 & Fair \\
\hline \multirow{4}{*}{ All } & Grade 7 & 2.86 & 0.75 & Fair \\
\hline & Grade 8 & 2.82 & 0.74 & Fair \\
\hline & Grade 9 & 2.95 & 0.55 & Fair \\
\hline & Total & 2.88 & 0.69 & Fair \\
\hline
\end{tabular}


PAPER

NEEDS ASSESSMENT OF INFORMATION AND COMMUNICATION TECHNOLOGY LiTERACY (ICT LiTERACY) OF STUDENTS...

TABLE III. RESULTS OF COMPARISON OF STUDENTS' ICT LITERACY DIVIDED BY LEVEL OF STUDY

\begin{tabular}{|c|c|c|c|c|c|c|}
\hline Standard & Source of Variation & SS & df & MS & $\mathbf{F}$ & $\mathbf{P}$ \\
\hline \multirow[t]{3}{*}{ Define } & Between Groups & 0.51 & 2 & .025 & .052 & .949 \\
\hline & Within Groups & 163.573 & 337 & .485 & & \\
\hline & Total & 163.624 & 339 & & & \\
\hline \multirow[t]{3}{*}{ Access } & Between Groups & .328 & 2 & .164 & .267 & .766 \\
\hline & Within Groups & 207.447 & 337 & .616 & & \\
\hline & Total & 207.775 & 339 & & & \\
\hline \multirow[t]{3}{*}{ Manage } & Between Groups & 2.887 & 2 & 1.444 & 2.045 & .131 \\
\hline & Within Groups & 237.934 & 337 & .706 & & \\
\hline & Total & 240.821 & 339 & & & \\
\hline \multirow[t]{3}{*}{ Evaluate } & Between Groups & .399 & 2 & .199 & .432 & 649 \\
\hline & Within Groups & 155.385 & 337 & .461 & & \\
\hline & Total & 155.784 & 339 & & & \\
\hline \multirow[t]{3}{*}{ Integrate } & Between Groups & 1.247 & 2 & .623 & 1.353 & .260 \\
\hline & Within Groups & 155.229 & 337 & .461 & & \\
\hline & Total & 156.475 & 339 & & & \\
\hline \multirow[t]{3}{*}{ Create } & Between Groups & 3.015 & 2 & 1.507 & 2.443 & .088 \\
\hline & Within Groups & 207.969 & 337 & .617 & & \\
\hline & Total & 210.984 & 339 & & & \\
\hline \multirow[t]{3}{*}{ Communicate } & Between Groups & 3.132 & 2 & 1.566 & 2.769 & .064 \\
\hline & Within Groups & 190.596 & 337 & .566 & & \\
\hline & Total & 193.728 & 339 & & & \\
\hline \multirow[t]{3}{*}{ All } & Between Groups & .927 & 2 & .463 & .982 & .375 \\
\hline & Within Groups & 158.980 & 337 & .472 & & \\
\hline & Total & 159.907 & 339 & & & \\
\hline
\end{tabular}

TABLE IV. RESUlts OF PRIORITY NEEDS INDEX MODIFIED: PNI MODIFIED $_{\text {Th }}$

\begin{tabular}{|c|c|c|c|c|}
\hline Components & AVG. of authentic situation (D) & AVG. of expected situation (I) & PNI $_{\text {modified }}$ & Rank \\
\hline Define & 2.84 & 4.75 & 0.67 & 4 \\
\hline Access & 2.88 & 4.80 & 0.66 & 5 \\
\hline Manage & 2.79 & 4.84 & 0.74 & 1 \\
\hline Evaluate & 2.85 & 4.83 & 0.70 & 2 \\
\hline Integrate & 2.87 & 4.74 & 0.65 & 6 \\
\hline Create & 2.89 & 4.84 & 0.68 & 3 \\
\hline Communicate & 3.00 & 4.81 & 0.60 & 7 \\
\hline
\end{tabular}

authentic

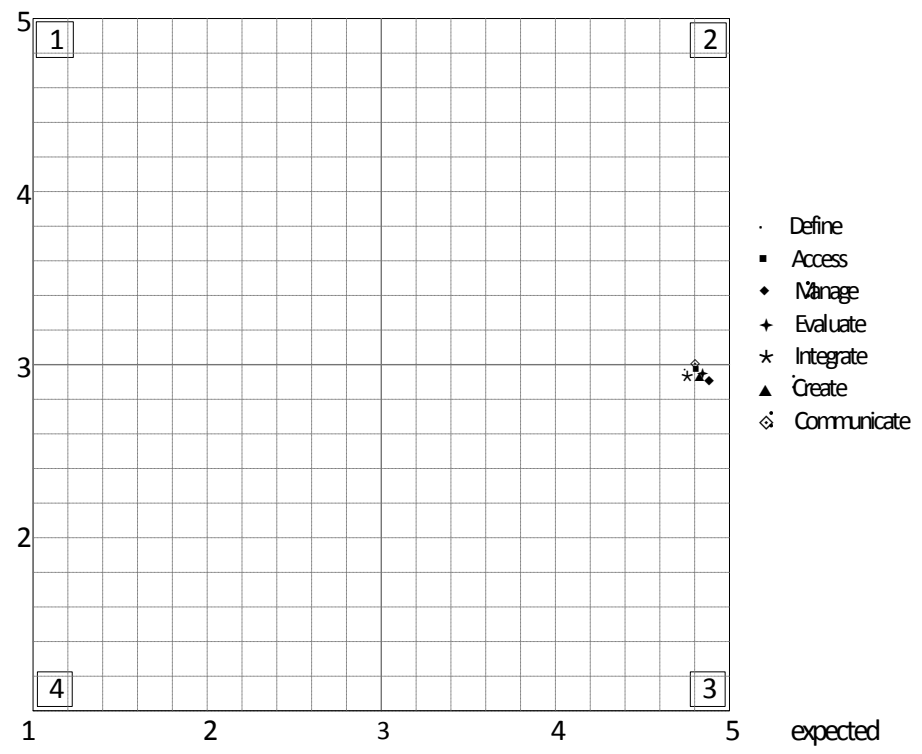

Figure 1. Results of Matrix Analysis 


\section{DISCUSSION}

1. The authentic situation of ICT literacy of students in secondary educational service area found at moderate level in which it should be in higher level to meet curriculum standard. The findings shows that students need to be improved in ICT literacy. The reasons can be explained from curriculum, when is used, does not promote students the ICT literacy As the Institute for the Promotion of Teaching Science and Technology (IPST) states that ICT learning management course emphasises on contents more than application in daily tasks and the lack of integration with other subjects. Moreover, course evaluation and measurement focus to measure its theories rather thinking and problem solving skills [11]. The findings also relate to the study of Garba, Byabazaire and Busthami [12] that Malaysian teachers do not integrate ICT with other subjects. Their learning management still focuses on teacher centre rather than student centre.

2. The Grade 7, 8 and 9 students in secondary educational service area have no difference in ICT literacy. Since the core curriculum modified in 2008 was operated in all schools, students receive the same pattern of ICT learning. The contents are almost similar in each levels. The curriculum encourages students all three levels in ICT learning similarly.

3. According to Matrix analysis, need assessment of students' ICT literacy should be improved. This finding relates to results of International Computer and Information Literacy Study (ICILS, 2013). It shows that Thailand rank at 17 th out of 18 countries in ICT literacy study. This reflects the levels of Thai students' ICT literacy; search, check, create and communicate at low level [8]. In addition, Pernia (2008) [13] suggests that Thailand's policy promote students in ICT literacy, however; the lack of resources and knowledge in ICT of Thailand effect the achievement of students' ICT literacy. The suggestions focus on enhancing more students' ICT skill.

4. The priority of need assessment of students' ICT literacy can be ranked from most needed to least needed as follows: Manage, Evaluate, Create, Define, Access, Integrate and Communicate, respectively. It shows that the protection of information is the first components to be improved. California Emerging Technology Fund [14] states some significant components to manage information that should be prioritized, for example, basic implementation of access information and the process of applying information in future. Moreover, when considered the next PNI modified, there is no difference from the first component. This confirms that each components should also be improved.

\section{SugGESTIONS}

1. The need assessment of ICT literacy in other sampling groups should be focused such as higher education group, working people group and students from others educational areas in order to explore problem at national level and find further solutions.

2. The core curriculum should be developed or it should provide extra curricular activities to enhance students' ICT literacy.

\section{REFERENCES}

[1] Partnership for 21st century skills. 2009. Framework for 21st Century Learning. [Online]. Available from: http://www.p21.org/storage/documents/ P21_Framework.pdf.

[2] Murray, Janet. 2008. "Looking at ICT Literacy Standards Thought the Big6 Lens." Library Media Connection. April/May 2008, 4041.

[3] Ministry of Education of Malaysia. 2012. Malaysia Education Blueprint 2013-2025. [Online]. Available: http://www.moe. gov.my/userfiles/file/PPP/Preliminary-Blueprint-Eng.pdf.

[4] MCEETYA. 2005. National Assessment Program Information and Communication Technology Literacy 2005 Year 6 and 10 Report. [Online]. Available from: http://www.nap.edu.au/ver ve/ resources/2005 ICTL Public Report.pdf.

[5] 21st Century Literacy Summit. 2003. 21st century literacy in a convergent media world [White paper]. [Online]. Available: http://www.21stcenturyliteracy.org/white/WhitePaperEnglish.pdf.

[6] Katz, I. R. and others. 2004. Assessing information and communication technology literacy for higher education. [Online]. Available from: http://www.ets.org/iaea.

[7] Ministry of Information and Communication Technology. 2011. Information and Communication Technology Policy Framework of Thailand 2011-2019. Bangkok: Ministry of Information and Communication Technology.

[8] Fraillon, J and others. 2014. Preparing for Life in a Digital Age. The IEA International Computer and Information Literacy Study International Report. Melbourne: Springer, Cham.

[9] Yamane, Taro. 1973. Statistics: An Introductory Analysis. 3rdEd. New York: Harper and Row Publications.

[10] Wongwanich, Suvimol. 2015. Needs Assessment. 3rd ed. Bangkok. Chulalongkorn University Printing.

[11] The Institute for the Promotion of Teaching Science and Technology. 2015. International Computer and Information Literacy Study International Report. Bangkok. IPST.

[12] Garba, S.A. , Byabazaire, Y. and Busthami, A.H. 2015. "Toward the Use of 21st Century Teaching-Learning Approaches: The Trend of Development in Malaysian Schools within the Context of Asia Pacific." International Journal of Emerging Technologies in Learning. 10(4): 72-79. https://doi.org/10.3991/ijet.v10i4.4717

[13] Pernia, Elana E. 2008. Strategy Framework for promoting ICT literacy in the Asia-Pacific region. Bangkok: UNESCO Bangkok.

[14] California Emerging Technology Fund. 2008. California ICT Digital Literacy Assessments and Curriculum Framework. [Online]. Available: http://www.ictliteracy.info/rf.pdf/California\% 20ICT\%20Assessments\%20and\%20Curriculum\%20Framework.p $\underline{\mathrm{df}}$

\section{AUTHORS}

Patcharapon Thammasaeng is with the King Mongkut's Institute of Technology Ladkrabang, Faculty of Industrial Education, Bangkok, Thailand 10520 (email:patcharapon@gmail.com).

Padungchai Pupat is with the King Mongkut's Institute of Technology Ladkrabang, Faculty of Industrial Education, Bangkok, Thailand 10520 (email:pdc_2500@yahoo.com).

Sawat Phetchaboon is with the Horwang Secondary School, Chatuchak, Bangkok, Thailand 10900 (email:sawatphet@yahoo.com).

Submitted 27 April 2016. Published as resubmitted by the authors 07 June 2016. 